\title{
Karpal Tünel Sendromunda İnflamasyonun Nötrofil-Lenfosit Oranı, Platelet- Lenfosit Oranı ve Ortalama Platelet Hacmi ile Değerlendirilmesi
}

\author{
Erman Altunışık*, Ali Zeynel Abidin Tak
}

DOI: $10.17944 / \mathrm{mkutfd} .790592$

Erman Altunışık: Dr. Öğr. Üyesi, Adıyaman Üniversitesi Eğitim Araștırma Hastanesi Nöroloji Anabilim Dalı, Adıyaman

Email: ermanaltunisik@gmail.com ORCID iD: https://orcid.org/0000-0002-5996-2090

Ali Zeynel Abidin Tak: Doç. Dr., Adıyaman Üniversitesi Eğitim Araștırma Hastanesi Nöroloji Anabilim Dalı, Adıyaman

Email: alizeyneltak@gmail.com

ORCID iD: https://orcid.org/0000-0002-3783-184X

Bildirimler/Acknowledgement

* Sorumlu Yazar/Corresponding Author

Çıkar Çatıșması/Conflict of Interest Yazarlar bu makale ile ilgili herhangi bir çıar çatıșması bildirmemișlerdir.

The authors declare that they have no conflict of interests regarding content of this article.

Maddi Destek/Financial Support Yazarlar bu makale ile ilgili herhangi bir finansal destek bildirmemișlerdir.

The Authors report no financial support regarding content of this article.

\section{Etik Beyan/Ethical Declaration}

Bu çalıșma için Adıyaman Üniversitesi Girișimsel Olmayan Klinik Araștırmalar Etik Kurulundan 14.01.2020 tarih ve 2020/1-29 sayll yazı ile izin alınmıș olup Helsinki Bildirgesi kriterleri göz önünde bulundurulmuștur.

Ethical approval was obtained from Adıyaman University Clinical Research Ethical Committee with date 14.01.2020 and number 2020/1-29 and Helsinki Declaration rules were followed to conduct this study.

Geliș/Received: 04.09.2020

Düzeltme/Revised: 06.09 .2020

Kabul/Accepted: 08.09.2020

e-ISSN: 2149-3103

Web: http://dergipark.org.tr/mkutfd 0̈z

Karpal Tünel Sendromunda Inflamasyonun Nötrofil-Lenfosit Oranı, Platelet-Lenfosit Oranı ve Ortalama Platelet Hacmi ile Değerlendirilmesi

Amaç: Karpal tünel sendromu median sinirin karpal tünel seviyesinde sıkıșmasından kaynaklanan ve en yaygın görülen mononöropati șeklidir. Büyük bir kısmı idiopatik olan bu tablonun fizyopatolojik mekanizması halen tam açıklanamamıștır. Bu çalıșmada karpal tünel sendromunda sistemik inflamasyonun olası rolünün nötrofil-lenfosit oranı, platelet-lenfosit oranı ve ortalama platelet hacmi değerleri ile incelenmesi amaçlanmıştır.

Gereç ve Yöntem: Çalıșmaya yașları 20 ve 60 arasında değișen, elektrofizyoloji laboratuvarımıza refere edilen ve Amerikan Nöroloji Akademisi kriterlerine göre karpal tünel sendromu tanısı konulan toplam 55 hasta ve sağlıklı 36 kiși dahil edildi. Hastalar elektrofizyolojik bulgulara göre hafif, orta ve șiddetli olmak üzere üç alt gruba ayrıldı. Hastaların klinik açıdan fonksiyonel durumları ve hastalık șiddetleri Boston Questionnaire ile değerlendirildi.

Bulgular: Çalıșmaya dahil edilen 91 hastanın $71^{\prime} \mathrm{i}(\% 78,02)$ kadın ve 20'si $(\% 21,98)$ erkekti. Hasta grubu yaș ortala-

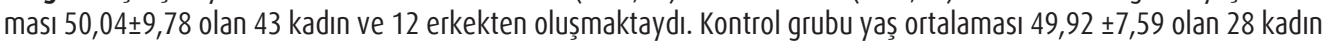
ve 8 erkekten olușmaktaydı. Hasta ve kontrol grupları karșılaștırıldığında nötrofil-lenfosit oranı, platelet-lenfosit oranı ve ortalama platelet hacmi değerleri arasında anlamlı fark saptanmadı. Ölçülen değerler hasta alt gruplarında karșılaștırıldığında hastalık șiddetiyle değerler arasında anlamlı fark saptanmadı.

Sonuç: Karpal tünel sendromu patofizyolojisinde sistemik inflamasyonun rolünün belirsiz olduğu, bazı mekanik ve lokal patolojilerin etyopatogenezi aydınlatmakta daha ön planda düşünülmesi gerektiği akla yatkın görünmektedir. Konu ile ilgili hasta sayısının artııılığı çok merkezli ve uzunlamasına çalışmalara ihtiyaç olduğu kanaatine varıldı.

Anahtar Kelimeler: Karpal Tünel Sendromu, Median Sinir, Nötrofil-Lenfosit Oranı, Platelet-Lenfosit Oranı, Ortalama Platelet Hacmi, İnflamasyon, Mononöropati

\section{Abstract}

Evaluation of Inflammation in the Carpal Tunnel Syndrome by the Neutrophil-Lymphocyte Rate, Platelet- Lymphocyte Rate and Mean Platelet Volume

objective: Carpal tunnel syndrome is the most common form of mononeuropathy caused by compression of the median nerve at the carpal tunnel level. The pathophysiological mechanism of this picture, which is mostly idiopathic, is still not fully explained. The aim of this study to examine the possible role of inflammation in carpal tunnel syndrome with neutrophil-lymphocyte ratio, platelet-lymphocyte ratio and mean platelet volume values.

Materials and Methods: A total of 55 patients aged between 20 and 60 years, referred to our electrophysiology laboratory and diagnosed with carpal tunnel syndrome according to the American Academy of Neurology criteria and 36 healthy participants were included in the study. Patients were divided into three subgroups as mild, moderate and severe according to electrophysiological findings. Clinical functional status and disease severity of patients were evaluated with Boston Questionnaire.

Results: 71 women (78.02\%) and 20 men (21.98\%), were included in the study. The patient group consists of 43 women and 12 men, with an average age of $50.04 \pm 9.78$. The control group consists of 28 women and 8 men with an average age of $49.92 \pm 7.59$. When compared between patient and control groups, no significant difference was found between neutrophil-lymphocyte ratio, platelet-lymphocyte ratio and mean platelet volume values. When the measured values were compared in the patient subgroups, there was no significant difference between disease severity and values.

Conclusions: The role of systemic inflammation in carpal tunnel syndrome pathophysiology is uncertain, it seems plausible that some mechanical and local pathologies should be considered in the foreground to elucidate the etiopathogenesis. It was concluded that multi-center and longitudinal studies with increased number of patients on the subject are needed.

Keywords: Carpal Tunnel Syndrome, Median Nerve, Neutrophil-Lymphocyte ratio, Platelet-Lymphocyte ratio, Mean Platelet Volume, Inflammation, Mononeuropathy 


\section{GİRIŞ̧}

Karpal tünel sendromu (KTS) median sinirin karpal tünel seviyesinde sıkışmasından kaynaklanan ve en yaygın görülen mononöropati şeklidir $(1,2)$. Hastalar en çok ağrı, parestezi daha az sıklıkta median sinirin innervasyon bölgelerinde motor kayıptan yakınırlar (3). Vakaların büyük çoğunluğu idiopatiktir. Özellikle $40-60$ yaș arası kadın popülasyonunda daha sık gözlenmektedir. Yüzde 50-60 oranında bilateral olma eğilimindedir (1). KTS gelişimi için obezite, kadın cinsiyet, eşlik eden inflamatuar hastalıklar (romatoid artrit, diyabet ve yumuşak doku hastalıkları), gebelik, genetik faktörler, çalışma koşulları risk faktörleri olarak belirlenmiştir $(4,5)$.

KTS patofizyolojisi multifaktoriyeldir ve gelişiminde intrakarpal kanal basıncının artışı anahtar bir rol oynamaktadır (6). Karpal tünelde anormal artmış basınç median siniri doğrudan zedeleyerek aksonal hasara neden olabileceği gibi; perineumdaki vasküler yapılara baskı oluşturarak median sinir iskemisine de yol açabilir (7).

Manyetik rezonans görüntüleme kullanan son çalışmalar idiyopatik KTS'de en sık karşılaşılan anormalliğin tenosinovyal kalınlaşma olduğunu açıkça göstermiştir (8). Kalınlaşan ve prolifere olan tenosinoviyumun yanında vasküler duvar kalınlaşması ve intimal hiperplazi gibi birtakım vasküler lezyonların da KTS'de sık gözlendiği belirtilmiştir (9). Median sinirin kompresyonuna ve traksiyonuna neden olan patofizyolojik mekanizmalar karmaşıktır ve henüz net anlaşılamamıştır. Bazı çalışmalarda kronik inflamasyonun rolü üzerinde durulmuştur (2).

Nötrofil-lenfosit oranı (NLR) sistemik inflamasyon belirteci olarak son yıllarda araştırılan ve diğer inflamasyon belirteçlerine göre düşük maliyetli, pratik ve basit uygulanabilen yeni bir yöntemdir (10). Platelet lenfosit oranının (PLR) da benzer şekilde NLR gibi sistemik inflamasyon göstergesi olduğu hatta NLR ile birlikte değerlendirildiğinde daha anlamlı bir belirteç olduğunu gösteren çalışmalar mevcuttur (11). Ortalama platelet hacmi (MPV) platelet fonksiyon ve aktivasyonunun göstergesidir (12). MPV düzeylerinin romatoid artrit, ankilozan spondilit, psöriasiz gibi birçok kronik inflamatuar hastalıkta prediktif değeri olduğu gösterilmiştir (5). Bu çalışmada KTS etyopatogenezinde inflamasyonun olası rolünün NLR, PLR ve MPV değerleri ile incelenmesi amaçland.

\section{GEREÇ VE YÖNTEMLER}

Çalışmaya yaşları 20 ve 60 arasında değişen, elektrofizyoloji laboratuvarına refere edilen ve Amerikan Nöroloji Akademisi kriterlerine göre KTS tanısı konulan toplam 55 hasta dahil edildi (13). Median siniri etkileyebilecek radikülopati, pleksopati ve travmatik sinir hasarı olanlar çalış- maya alınmadı. Kronik böbrek yetmezliği, kronik karaciğer yetmezliği, diyabet, hipotroidi ve konnektif doku hastalığı gibi sistemik hastalığı olanlar çalışma dışı bırakıldı. Hematolojik hastalık, sistemik inflamatuar hastalık, malignite, gebelik, kalp yetmezliği olanlar, son 1 ay içinde cerrahi girişim öyküsü olanlar, son 2 hafta içinde enfeksiyon geçirenler, antibiyotik, antiagregan, antikoagülan ve immünsupresan ajan kullananlar da çalışma dışı bırakıldı. Hastaların klinik açıdan fonksiyonel durumları ve hastalık şiddetleri Boston Questionnaire (BQ) ile değerlendirildi. BQ KTS'de semptom şiddeti ve fonksiyonel durum için bir değerlendirme aracıdır (14). Anket Symptom Severity Scale (SSS) ve Functional Status Scale (FSS) olmak üzere iki bölümden oluşur. SSS, skorları 1 (en hafif) ve 5 (en şiddetli) arasında değişen toplam 11 sorudan oluşur. 11 skorun ortalaması hesaplanarak genel sonuç bulunur. FSS, seçilen faaliyetleri gerçekleştirmedeki zorlukları değerlendiren 8 sorudan oluşur. Fonksiyonel durum için toplam puan, sekiz skorun ortalaması olarak hesaplanır (15). Kontrol grubu EMG laboratuvarına yönlendirilen ve sinir ileti çalışması sonuçları normal olan 60 yaş altında toplam 36 sağlıklı gönüllü bireyden oluşturuldu. Kontrol grubunun yaş, vücut kitle indeksi (BMI), SSS ve FSS skorları kaydedildi.

\subsection{Elektrofizyolojik Ölçümler}

KTS tanısı aynı kullanıcı tarafindan Medelec Synergy (Oxford Instruments Medical, Inc, UK) elektronöromyografi (ENMG) cihazı kullanılarak, 2. parmaktan kaydedilen median sinir pik duyu iletim hızının $50 \mathrm{~m} / \mathrm{sn}$ 'den yavaş olması ve/veya motor iletim çalıșmasında abduktör pollicis brevis kasından kayıtla median sinirin 5 cm'lik bilek segmentinden uyarılması ile distal motor latansin 4.5 msn'den uzun olması durumu olarak değerlendirildi. Duyusal sinir aksiyon potansiyellerinin (SNAP) genliği tepeden tepeye, bileşik kas aksiyon potansiyellerinin (CMAP) genliği, potansiyelin başlangıcından negatif zirveye kadar ölçülerek hesaplandı. Kolun cilt sıcaklığı bir kızılötesi lamba ile $30^{\circ}$ C'nin üzerinde sabit tutuldu. Filtreleme motor iletiler için $5 \mathrm{~Hz}-10 \mathrm{kHz}$ ve duyusal iletiler için $20 \mathrm{~Hz}-2 \mathrm{kHz}$ olarak yapıldı. Uyarı süresi $0.1 \mathrm{~ms}$ olarak tutuldu. Sinir ileti çalışması sonucunda median nöropati saptanan hastalar hafif, orta ve şiddetli olmak üzere üç alt kategoriye ayrıldı. Sinir ileti hızı $50 \mathrm{~m} / \mathrm{sn}$ altında olanlar hafif, sinir ileti hızı $50 \mathrm{~m} /$ sn altında ve distal motor latans $4.5 \mathrm{~ms}$ üzerinde olanlar orta, duyusal sinir uyarımı elde edilemeyen hastalar ağır KTS olarak gruplandırıldı (16).

\subsection{Hematolojik Analiz}

Hasta ve kontrol grubundan 8 saatlik açlı̆g takiben antekubital venöz kan örnekleri alındı. Alınan kan örnekleri 30 dakika santifürüj edildi ve aynı gün hastanemiz biyokimya laboratuvarında CELL-DYN 3700 SL (Abbott Diag- 
Tablo 1. Hasta ve kontrol gruplarının klinik ve demografik özellikleri

\begin{tabular}{|l|c|c|c|}
\hline & Hasta & Kontrol & p \\
\hline Yaş (Yll) & $50,04 \pm 9,78$ & $49,92 \pm 7,59$ & 0,564 \\
\hline Cinsiyet (K/E) & $43 / 12$ & $28 / 8$ & 0,964 \\
\hline BMI $\left(\mathbf{k g} / \mathbf{m}^{2}\right)$ & $27,02 \pm 3,07$ & $27,17 \pm 2,76$ & 0,818 \\
\hline NLR & $1,93 \pm 0,74$ & $1,93 \pm 0,60$ & 0,581 \\
\hline PLR & $106,05 \pm 27,69$ & $106,26 \pm 37,94$ & 0,703 \\
\hline MPV & $8,32 \pm 1,43$ & $7,80 \pm 1,18$ & 0,073 \\
\hline SSS & $32,51 \pm 8,78$ & $11,00 \pm, 00$ & $<\mathbf{0 . 0 0 1}{ }^{*}$ \\
\hline FSS & $22,47 \pm 5,47$ & $8,00 \pm, 00$ & $<\mathbf{0 . 0 0 1 *}$ \\
\hline SSS: & &
\end{tabular}

SSS: Semptom ciddiyeti skalası; FSS: Fonksiyonel durum skalası; BMI: vucut kitle indeksi; NLR: Notrofil lenfosit oranı; PLR: Platelet lenfosit oranl; MPV: ortalama trombosit hacmi; Kruskal Wallis Test ANOVA

nostics, Chicago, USA) cihazında analiz edildi. NLR, nötrofil sayısının lenfosit sayısına bölünmesiyle, PLR trombosit sayısının lenfosit sayısına bölünmesiyle hesaplandı.

\section{3. İstatistiksel Analiz}

İstatistiksel analizler SPSS versiyon 17.0 programı yardımıyla gerçekleştirildi. Değiş̧kenlerin normal dağılıma uygunluğu histogram grafikleri ve Kolmogorov-Smirnov testi ile incelendi. Tanımlayıcı analizler sunulurken ortalama, standart sapma, ortanca değerler kullanıldı. 2x2 gözlerde Pearson Ki Kare ve Fisher's Exact Testleri ile karşılaştırıldı. Normal dağılım gösteren (parametrik) değişkenler iki grup arasında değerlendirilirken Bağımsız gruplarda T Testi, ikiden fazla grup arasında değerlendirilirken ANOVA testi kullanıldı. Normal dağılım göstermeyen (nonparametrik) değişkenler iki grup arasında değerlendirilirken Mann Whitney U Testi, ikiden fazla grup arasında değerlendirilirken Kruskal Wallis Testi kullanıldı. P-değerinin 0.05'in altında olması istatistiksel yönden anlamlı olarak değerlendirildi.

\section{Etik Beyan}

Bu çalışma için Adıyaman Üniversitesi Girişimsel Olmayan Klinik Araştırmalar Etik Kurulundan 14.01.2020 tarih ve 2020/1-29 sayılı yazı ile izin alınmış olup Helsinki Bildirgesi kriterleri göz önünde bulundurulmuştur.

\section{BULGULAR}

Çalışmaya 71 kadın $(\% 78,02)$ ve 20 erkek $(\% 21,98)$ olmak üzere toplam 91 kişi dahil edildi. Bunlardan 55'i $(\% 60,44)$ hasta grubunda, 36'sı $(\% 39,56)$ kontrol grubundaydı. Hasta grubu yaş ortalaması $50,04 \pm 9,78$ olan 43 kadın ve 12 erkekten oluşmaktaydı. Kontrol grubu ise yaş ortalaması 49,92 $\pm 7,59$ olan 28 kadın ve 8 erkekten oluşmaktaydı. Hastaların 20 'sinin $(\% 36,36)$ hastalığ hafif, 20'sinin $(\% 36,36)$ orta ve 15 'inin $(\% 27,27)$ şiddetliydi.

\begin{tabular}{|c|c|c|c|}
\hline \multicolumn{4}{|c|}{ Tablo 2. Hasta ve kontrol gruplarının elektrofizyolojik bulguları } \\
\hline & Hasta & Kontrol & $\mathbf{p}$ \\
\hline & Ort \pm SS & Ort \pm SS & \\
\hline DMLL & $4,47 \pm 1,26$ & $2,83 \pm, 30$ & $<0,001$ \\
\hline DMLR & $4,87 \pm 1,40$ & $2,91 \pm, 39$ & $<0,001$ \\
\hline MNCVL & $54,83 \pm 12,03$ & $60,41 \pm 4,81$ & $<0,001$ \\
\hline MNCVR & $48,69 \pm 17,99$ & $60,21 \pm 4,38$ & $<0,001$ \\
\hline CMAPL & $6,78 \pm 2,64$ & $8,78 \pm 2,43$ & $<0,001$ \\
\hline CMAPR & $5,82 \pm 2,94$ & $8,60 \pm 2,81$ & $<0,001$ \\
\hline DSLL & $3,64 \pm, 93$ & $2,26 \pm, 19$ & $<0,001$ \\
\hline DSLR & $3,77 \pm, 79$ & $2,29 \pm, 19$ & $<0,001$ \\
\hline SNCVL & $36,61 \pm 13,22$ & $59,21 \pm 4,66$ & $<0,001$ \\
\hline SNCVR & $29,32 \pm 18,38$ & $58,46 \pm 4,74$ & $<0,001$ \\
\hline SNAPL & $16,16 \pm 10,63$ & $44,97 \pm 16,20$ & $<0,001$ \\
\hline SNAPR & $12,37 \pm 10,60$ & $41,65 \pm 16,05$ & $<0,001$ \\
\hline \multicolumn{4}{|c|}{$\begin{array}{l}\text { DML: Distal motor latans; MNCV: Motor sinir ileti hızl; CMAP: Bilessik kas aksiyon potansiyeli; } \\
\text { DSL: Distal duyu latansı; SNCV: Duyu sinir ileti hızi; SNAP: Duyusal sinir aksiyon potansiyeli. } \\
\text { Ort: ortalama, SS: Standart sapma, Mann Whitney U Testi, Bağımsız T Testi }\end{array}$} \\
\hline
\end{tabular}

Hasta ve kontrol grupları yaş, cinsiyet ve BMI açısından benzer özelliklerdeydi. ( $p>0.05)$. Hasta ve kontrol gruplarının klinik ve demografik özellikleri Tablo 1'de gösterilmiştir. Bu iki gruptaki elektrofizyolojik bulgular Tablo 2'de özetlenmiştir. Ölçülen değerler hasta ve kontrol grupları arasında karşılaştırıldığında NLR, PLR ve MPV değerleri arasında anlamlı fark saptanmadı. Ölçülen değerler hasta alt gruplarında karşılaştırıldığında hastalık şiddetiyle değerler arasında anlamlı fark saptanmadı (Tablo 3). SSS ve FSS değerleri hasta grubunda kontrol grubuna göre anlamlı derecede daha yüksek saptandı $(\mathrm{p}<0.001)$. Hastalık şiddetli ile FSS değerleri arasında ilişki saptanmazken SSS değerleri ağır KTS'si olanlarda, hafif ve orta dereceli KTS'si olanlara göre anlamlı derecede yüksek bulundu $(\mathrm{p}<0.001)$.

Kan parametrelerinden ölçülen toplam beyaz küre sayısı (WBC), nötrofil sayısı (NEU), lenfosit sayısı (LYM), platalet sayısı (PLT), hemoglobin değeri (HBG) gibi diğer değerler gerek hasta ve kontrol grupları arasında gerekse hastalık şiddetine göre hasta alt grupları arasında kıyaslandığında istatistiksel olarak anlamlı fark saptanmadı

\begin{tabular}{|l|l|l|l|l|}
\multicolumn{5}{|c|}{ Tablo 3. Ölçülen değerlerin hasta alt grupları arasında karşılaştırılması } \\
\hline & Hafif (Ort \pm SS) & \multicolumn{1}{|c|}{ Orta (Ort \pm SS) } & $\begin{array}{c}\text { Şiddetli } \\
\text { (Ort } \pm \text { SS) }\end{array}$ & p \\
\hline Yaş & $46,30 \pm 11,68$ & $50,55 \pm 8,48$ & $54,33 \pm 6,83$ & 0,046 \\
\hline MPV & $8,35 \pm 1,78$ & $8,41 \pm 1,37$ & $8,16 \pm 1,01$ & 0,876 \\
\hline NLR & $1,89 \pm 0,58$ & $1,86 \pm, 87$ & $2,09 \pm, 78$ & 0,585 \\
\hline PLR & $100,66 \pm 24,59$ & $104,81 \pm 32,12$ & $114,89 \pm 24,68$ & 0,209 \\
\hline SSS & $28,35 \pm 5,64$ & $27,85 \pm 4,79$ & $44,27 \pm 4,37$ & $<0,001$ \\
\hline FSS & $22,40 \pm 6,03$ & $22,65 \pm 5,59$ & $22,33 \pm 4,86$ & 0,964 \\
\hline
\end{tabular}

SSS: Semptom ciddiyeti skalası; FSS: Fonksiyonel durum skalası; NLR: Nötrofil lenfosit oranı; PLR: Platelet lenfosit oranı; MPV: ortalama trombosit hacmi Kruskal Wallis Test ANOVA 


\section{TARTIŞMA}

KTS, karpal tunel içerisindeki artmış basıncın rol oynadığı multifaktöryel bir hastalıktır (6). Büyük bir kısmı idiopatik olan bu durumun fizyopatolojik mekanizması tam açıklanabilmiş değildir (17). Bilgilerimize göre daha önce yapılan hiçbir çalışmada KTS’nin enflamatuar belirteçlerden NLR, PLR ve MPV'nin üçü ile birlikte ilişkisi incelenmemiştir. Buradan hareketle, etyopatogenezi halen tam olarak aydınlatılamamış olan bu hastalıkta son yıllarda inflamasyon belirteci olarak kullanılan bu parametreleri kullanarak sistemik inflamasyonun rolünün araştırılması amaçlandı.

Ölçülen NLR, PLR ve MPV değerleri hasta ve kontrol grupları arasında karşılaştırıldığında değerler arasında anlamlı fark saptanmadı. Ölçülen değerler elektrofizyolojik olarak belirlenmiş hasta alt grupları arasında karşılaştırıldığında hastalık şiddetiyle değerler arasında anlamlı fark görülmedi.

KTS'de patofizyolojiyi aydınlatmaya yönelik olarak yapılan bazı histopatolojik çalıșmalar mevcuttur. Yapılan iki çalışmada tenosinovyumda herhangi bir inflamatuar bulgu saptanmamıştır $(18,19)$. Farklı bir çalışmada 35 KTS hastasının sadece 4'ünde tenosinovyumda hafif kronik inflamatuar değişiklikler saptanmıştır (20). Bir başka çalışmada hastaların sadece yüzde 10'unda perivasküler lenfotik infiltrasyon ve yüzde 7'sinde fibroz sinovit saptanmıştır (21). Yapilan bir vaka sunumunda KTS'si olan bir Hodgkin Dıșı Lenfoma hastasının pozitron emisyon tomografisinde (PET/BT) insidental olarak sağ el bileğinde non spesifik artmış fluoro-2-deoksi-glikoz (FDG) tutulumu saptanmış ve bu durum inflamatuar etkenler lehine olduğu şeklinde yorumlanmıştır (22). Görüldügü üzere histopatolojik çalışmalar KTS'nin altta yatan patofizyolojik mekanizmasında inflamatuvar etkenlerin rol oynadığını ispat etmekten uzaktır.

KTS hastalarında sistemik inflamatuar parametrelerin ölçüldüğü ve farklı sonuçların elde edildiği birtakım çalışmalar da mevcuttur. Bir çalışmada KTS hastalarında serum procalsitonin değerleri kontrol grubuna kıyasla anlamlı derecede yüksek bulunurken, C-reaktif protein değerleri arasında anlamlı fark saptanmamıștır. Aynı çalıșmada ölçülen değerler hastalık şiddetine göre hasta alt gruplarında karşılaştırılmış ve hasta alt gruplarında anlamlı fark bulunamamıștır (2). Bir başka çalıșmada KTS hastalarında interlökin 6 (IL-6) düzeyi kontrol grubuna kıyasla daha yüksek bulunurken, interlökin 1 (IL-1) değerleri arasında anlamlı fark saptanmamıştır (23). Bazı inflamatuar sitokinlerin ölçüldüğü bir başka çalışmada KTS hastalarında IL-1 ve tümör nekroz faktör alfa (TNF alfa) düzeyleri hasta ve kontrol gruplarında benzer bulunurken, IL-6 düzeyi hasta grubunda kontrol grubuna kıyasla anlamlı derecede yüksek saptanmıştır (24).
Literatür incelemesinde KTS hastalarında NLR ve PLR değerlerinin araştırıldığı bir çalışmaya rastlandı. Çalışmada KTS hastalarında NLR değerleri hasta grubunda kontrol grubuna göre daha yüksek bulunurken PLR değerleri arasında anlamlı fark saptanmamıștır (25). Bu çalıșmada da ölçülen PLR değerleri benzer bir şekilde hasta ve kontrol grupları arasında farklı değildi.

Geriatrik hasta grubu üzerinde yapılan bir çalışmada KTS hastalarında MPV değerleri kontrol grubuna kıyasla anlamlı derecede yüksek bulunmuştur. Bu durumun KTS hastalarında inflamasyonun göstergesi olduğu düşünülmüştür (5). Bu çalışmada MPV değerlerinde hasta ve kontrol grupları arasında anlamlı fark saptanmamıștır. Bahsi geçen çalışmayla bu çalışma arasında yaş gruplarının farklı olduğu göz ardı edilmemelidir.

Gerek sistemik parametrelerin ölçüldügüü gerekse histopatolojik incelemelerin yapıldığı çalışmalar KTS patofiztolojisinde sistemik inflamasyonun rolünün belirsiz olduğunu düşündürmektedir. Bazı mekanik ve lokal patolojilerin etyopatogenezi aydınlatmakta daha ön planda düşünülmesi gerektiği akla yatkın görünmektedir.

Çalışmada hasta grubunun SSS ve FSS değerleri kontrol grubuna göre anlamlı derecede yüksek bulunmuştur. Elektrodiagnostik olarak belirlenen hasta alt gruplarında şiddetli KTS olgularında SSS değeri, hafif ve orta şiddette olanlara göre daha yüksek bulunurken, FSS değerlerinde hasta alt grupları arasında anlamlı fark saptanmamıştır. Semptom ve fonksiyonel ölçeklerle elektrodiagnostik bulgular arasındaki ilișkiyi araștıran çalıșmalarda birbirinden farklı sonuçlar elde edilmiştir. Bazı çalışmalarda semptom ve fonksiyonel ölçek skorları ile, elektrofizyolojik olarak belirlenen hastalık şiddeti arasında anlamlı ilişki olmadığ bildirilmişken $(26,27)$, bazı çalışmalarda güçlü bir ilişki bulunmuştur $(28,29)$. Bir başka çalışmada şiddetli KTS hastalarında fonksiyonel kısitlllık daha yüksek bulunurken semptom şiddeti ile hastalık şiddeti arasında ilişki bulunmamıştır (30). Bulunan birbirinden farklı sonuçların altında yatan neden kullanılan ölçeklerin subjektif bulgulara dayanması olabilir. Ayrıca elektrofizyolojik bulguların büyük myelinli liflerde akson kaybı ve demyelinizasyon ortaya çıktıktan sonra aşikâr hale geldiği akılda tutulmalıdır (31).

Yaş KTS için önemli bir risk faktörüdür ve KTS öncelikle orta ve ileri yaş kadın popülasyonunda gözlenmektedir (32). Kadın cinsiyet idiopatik KTS için primer risk faktörlerinden biridir ve KTS kadınlarda erkeklere göre 3 kat daha fazla görülmektedir (33). Bu çalışmada da kadın erkek dağılımı benzer oranlardaydı. Ayrıca hastalığı şiddetli olanların yaş ortalaması hastalığı hafif olanlara göre daha yüksekti.

Bu çalışmanın bazı kısıtlılıkları mevcuttur. Çalışmaya katılan hasta sayısı nispeten azdır. Diğer bir olası kısıtlılık çalışmaya dahil edilen katılımcılara ait ilk başvuru anında 
uzun dönem takibi olmaksızın elde edilen tek bir laboratuvar örneği kullanılmasıdır. Ayrıca ölçülen değerler hastalık süresi ile kıyaslanmış olsaydı daha anlamlı sonuçlar elde edilebilirdi.

KTS patofizyolojisi karmaşıktır ve birçok etken altta yatan mekanizmada rol oynayabilir. Bu mekanizmalar arasında KTS'yi indükleyen en olası etken karpal tüneldeki artmış anormal basınçtır. Sistemik inflamasyonun bu basınç değiş̧ikliğindeki rolü net değildir. Her ne kadar bazı çalışmalar KTS'de lokal inflamatuar değişikliklerin olabileceğinden bahsetse de sistemik inflamatuar süreçlerin KTS patofizyolojisinde etken olduğunu söylemek çok mümkün görünmemektedir. Bu konunun doğrulanması için hasta sayısının artırıldığı çok merkezli randomize prospektif çalışmalara ihtiyaç vardır.

\section{Kaynaklar}

1. Michelsen H, Posner MA. Medical history of carpal tunnel syndrome. Hand Clin 2002; 18: 257 - 268. https://doi.org/10.1016/ S0749-0712(01)00006-3

2. Altun Y, Tak AZA. Can serum C-Reactive Protein and Procalcitonin levels associate with Carpal Tunnel Syndrome? Medical Science and Discovery 2019; 6: 18-23 https://doi.org/10.17546/msd.510957

3. Krom MC, Knipschild PG, Kester AD, Thijs CT, Boekkooi PF, Spaans F. Carpal tunnel syndrome: prevalence in the general population. J Clin Epidemiol 1992; 45: 373-6. https://doi.org/10.1016/08954356(92)90038-O

4. Keir PJ, Rempel DM. Pathomechanics of peripheral nerve loading. Evidence in carpal tunnel syndrome. J Hand Ther 2005; 18: 259-69. https://doi.org/10.1197/j.jht.2005.02.001

5. Tutoğlu A, Boyacı A, Kocatürk Ö, Sarıkaya S, Kul M, Karakaş EY, Yetişgin A. The relationship of carpal tunnel syndrome and mean platelet volume in geriatric patients Gaziantep Med J 2014; 20: 182185 https://doi.org/10.5455/GMJ-30-153778

6. Bland JD. Carpal tunnel syndrome. Curr Opin Neurol 2005; 18: 5815. https://doi.org/10.1097/01.wco.0000173142.58068.5a

7. Amirfeyz R, Gozzard C, Leslie IJ. Hand elevation test for assessment of carpal tunnel syndrome. J Hand Surg Br 2005; 30: 361-4. https:// doi.org/10.1016/J.JHSB.2005.04.007

8. Hirata H, Nagakura T, Tsujii M, Morita A, Fujisawa K, Uchida A The relationship of VEGF and PGE2 expression to extracellular matrix remodelling of the tenosynovium in the carpal tunnel syndrome. Pathol 2004; 204: 605-12 https://doi.org/10.1002/path.1673

9. Neal NC, McManners J, Stirling GA. Pathology of the flexor tendon sheath in the spontaneous carpal tunnel syndrome. J Hand Surg [Br] 1987; 12: 229-232. https://doi.org/10.1016/02667681(87)90020-9

10. Varım C, Acar BA, Uyanık MS, Acar T, Alagoz N, Nalbant A, Kaya T, Ergenc H. Association between the neutrophil-to- lymphocyteratio, a new marker of systemic inflammation, and restless legs syndrome. SingaporeMed J 2016; 57: 514-516 https:// doi.org/10.11622/smedj.2016154

11. Zhao QT, Zhang XP, Zhang H, Duan GC. Prognostic role of platelet to lymphocyte ratio in esophageal cancer: A meta-analysis. Oncotarget 2017; 20: 112085-112093. https://doi.org/10.18632/ oncotarget.22557

12. Bath PM, Butterworth RJ. Platelet size: measurement, physiology and vascular disease. Blood Coagul Fibrinolysis 1996; 7: 157-61. https://doi.org/10.1097/00001721-199603000-00011

13. American Academy of Neurology Practice parameter for carpal tunnel syndrome (summary statement): report of the Quality Standards Subcommittee of the American Academy of Neurology Neurology 1993; 43: 2406 - 2409. https://doi.org/10.1212/ WNL.43.11.2406

14. Kurt S, Çevik B, Kaplan Y et al. The relationship between Boston Questionnaire and electrophysiological findings in Carpal Tunnel Syndrome. Archives of Neuropsychiatry 2010; 47: 237-40.

15. Levine DW, Simmons BP, Koris MJ, et al. A self- administered questionnaire for the assessment of severity of symptoms and functional status in carpal tunnel syndrome. J Bone Surg (Am) 1993; 75: 1585-1592. https://doi.org/10.2106/00004623199311000-00002

16. Stevens JC. The electrodiagnosis of carpal tunnel syndrome. American Association of Electrodiagnostic Medicine. Muscle Nerve 1997; 20: 1477 - 1486. https://doi.org/10.1002/(SICI)10974598(199712)20:12<1477::AID-MUS1>3.0.CO;2-5

17. Chikenji T, Gingery A, Zhao C, et al. Transforming growth factor- $\beta$ (TGF- $\beta$ ) expression is increased in the subsynovial connective tissues of patients with idiopathic carpal tunnel syndrome. J Orthop Res 2014; 32: 116-122. https://doi.org/10.1002/jor.22485

18. Schuind F, Ventura M, Pasteels JL. Idiopathic carpal tunnel syndrome: Histologic study of flexor tendon synovium. J Hand Surg Am. 1990; 15: 497-503. https://doi.org/10.1016/03635023(90)90070-8

19. Kerr CD, Sybert DR, Albarracin NS. An analysis of the flexor synovium in idiopathic carpal tunnel syndrome: Report of 625 cases. J Hand Surg Am 1992; 17: 1028-1030. https://doi. org/10.1016/S0363-5023(09)91053-X

20. Scott KL, Conley CR, Renfree KJ Histopathologic Evaluation of Flexor Tenosynovium in Recurrent Carpal Tunnel Syndrome. Plast Reconstr Surg 2019; 143: 169-175 https://doi.org/10.1097/ PRS.0000000000005090

21. Faithfull DK, Moir DH, Ireland J. The micropathology of the typical carpal tunnel syndrome. J Hand Surg Br 1986; 11: 131-132. https:// doi.org/10.1016/0266-7681(86)90035-5

22. Joshi P, Lele V. Lighting the tunnel: FDG PET/CT findings leading to incidental diagnosis of carpal tunnel syndrome. Clin Nucl Med 2014; 39: 78-9. https://doi.org/10.1097/RLU.0b013e31827a276b

23. Freeland AE, Tucci MA, Barbieri RA, et al. Biochemical evaluation of serum and flexor tenosynovium in carpal tunnel syndrome. 
Microsurgery 2002; 22: 378- 385. https://doi.org/10.1002/ micr.10065

24. Takasu S, Takatsu S, Kunitomo K, Kokumai Y. Serum Hyaluronic Acid and Interleukin-6 as Possible Markers of Carpal Tunnel Syndrome in Chronic Hemodialysis Patients Artificial Organs 1994; 18: 420-42 https://doi.org/10.1111/j.1525-1594.1994.tb02227.x

25. Güneş M, Büyükgöl H. Correlation of neutrophil/lymphocyte and platelet/lymphocyte ratios with the severity of idiopathic carpal tunnel syndrome. Muscle Nerve 2020; 61: 369-374 https://doi. org/10.1002/mus.26791

26. Schrijver HM, Gerritsen AA, Strijers RL, et al. Correlating nerve conduction studies and clinical outcome measures on carpaltunnel syndrome: lessonsfrom a randomized controlled trial. J Clin Neurophysiol 2005; 22: 216-21.

27. Longstaff L, Milner RH, O'Sullivan S, Fawcett P. Carpaltunnel syndrome: the correlation between outcome, symptoms and nerve conduction study findings. J HandSurg [Br] 2001; 26: 475-80. https://doi.org/10.1054/jhsb.2001.0616

28. You H, Simmons Z, Freivalds A, Kothari MJ, Naidu SH. Relationships between clinical symptom severity scales and nevre conduction measures in carpal tunnel syndrome. Muscle Nerve 1999; 22: 497-501. https://doi.org/10.1002/(SICI)10974598(199904)22:4<497::AID-MUS11>3.0.CO;2-T

29. Dhong ES, Han SK, Lee BI, KimWK. Correlation of electrodiagnostic Findings with subjective symptoms in carpal tunnel syndrome. AnnPlastSurg 2000; 45: 127-31. https://doi.org/10.1097/00000637200045020-00005

30. Padua L, Padua R, Lo Monaco M, Aprile I, Tonali P. Multi perspective assessment of carpal tunnel syndrome: a multicenter study. Italian CTS Study Group. Neurology 1999; 53: 1654-9. https://doi. org/10.1212/WNL.53.8.1654

31. Dumitru D. Electrodiagnostic Medicine Philadelphia Hanley \& Belfus 1994: 864-867

32. Becker J, Nora DB, Gomes I, et al. An evaluation of gender, obesity, age and diabetes mellitus as risk factors for carpal tunnel syndrome. Clin Neurophysiol 2002; 113: 1429-1434. https://doi. org/10.1016/S1388-2457(02)00201-8

33. English JH, Gwynne-Jones DP. Incidence of carpal tunnel syndrome requiring surgical decompression. J Hand Surg Am 2015; 40: $2427-$ 2434 https://doi.org/10.1016/j.jhsa.2015.07.029 